\title{
The Practice of Corporate Governance in Companies Receiving Foreign Direct Investment in Cameroon
}

\author{
David Ngoungo \\ Faculty of Economics and Management Sciences \\ University of Yaounde II-Soa \\ P.O. Box 18 \\ Soa-Cameroon \\ Tel: +237-7532-8756_E-mail: ngoungo@yahoo.fr
}

$\begin{array}{lc}\text { Received: January 3, } 2012 & \text { Accepted: February 1, } 2012 \quad \text { Published: March 15, } 2012 \\ \text { doi:10.5430/rwe.v3n1p2 } & \text { URL: http://dx.doi.org/10.5430/rwe.v3n1p2 }\end{array}$

\begin{abstract}
This paper attempts to demonstrate that if investors activism (institutional or foreign) is considered as an enabling element for monitoring when capital is dispersed, such can, on the contrary, lead to the counter-performances of corporate governance in the case of highly concentrated ownership. With the help of factorial analysis, we classify companies receiving foreign direct investments (FDI) in Cameroon. A comparison of groups obtained reveal that $60 \%$ of the enterprises have a capital concentration of more than $50 \%$ in the hands of foreign investors and are identified as a contractual link to divergent interests, with dormant managers and employees, presence of few external administrators and insignificant or low returns.
\end{abstract}

Keywords: Companies Receiving FDI in Cameroon, Capital Concentration, Widened Governance, Alignment of Interests, Contractual Link

\section{Introduction}

For a couple of years, corporate governance has caught the attention of the media in particular, because of the result of the scandals that surround the life of enterprises in Cameroon as well as those abroad. We agree with Caby and Hirigoyen (2001) that it is an eternal question concerning the distribution of power.

The Organization for Economic Corporation and Development (OECD, 2001) defines corporate governance as "the mechanisms by which companies are managed and observed by the inside". According to Charreaux (1997), it is "all the organizational mechanisms which have the effect of limiting the powers and of influencing the decisions of the management, in other words, which govern their conduct and define their discretionary space". For Caby and Hirigoyen (2001), "Corporate governance covers the domain of the exercise of the decision rights, the effective management of the company...".

According to the above-mentioned definitions, corporate governance is formal organization and the distribution of power between shareholders, managers (employees) and the board of directors in large limited companies in view of assuring that the decisions of directors do not conflict with the interest of shareholders. It concerns the corporate governance known as 'shareholder' corporate governance whose major and unique objective is to satisfy the interest of shareholders (Jensen and Meckling, 1976).

Conceived and developed in a context in which the protection of national interests (markets, employees, suppliers, state, etc.) is imperative, companies in Cameroon that receive Foreign Direct Investments (FDI) must henceforth be able to reconcile the interests of shareholders (both national and foreign) on the one hand and, those of all stakeholders (both national and foreign) on the other hand.

From another viewpoint, foreign investors, just like institutional investors, represent influential partners for any company (Carleton and Al, 1998). Their financial means enables them to become active investors in the control of the management of the company especially when their participation in the capital of the company in more important than that of other shareholders. Thus, they have a significant influence on corporate governance. 
The important role of a shareholder in the system however depends on the proportion of capital he/she holds, as well as other elements like the number and nature of stakeholders, the number of interests to satisfy and the capacity of corporate governance to align the various interests. Thus, Gaby and Hirigoyen (2001) distinguish 'shareholder' corporate governance from 'partnership' or 'widened' corporate governance, distinguished by the objective pursued. When corporate governance is widened to all stakeholders, the objective of satisfying interests is extended to all stakeholders. In this case, the shareholders are neither residual decision makers nor exclusive holders of property right. Unlike the latter, 'shareholder' corporate governance encourages ownership concentration and the resurgence of influential shareholders who are ready to force management to meet, at all costs, the objective of satisfying the interests of shareholders only.

The above mentioned characteristics of corporate governance questions the capacity of companies in Cameroon that receive FDI to take advantage of it when ownership is highly concentrated in the hands of an influential shareholder and, in the presence of stakeholders and multiple interest to be satisfied.

To answer this question, this article tries to show that:

1. Companies receiving FDI in Cameroon have an ownership structure that is highly concentrated in the hands of a single shareholder who can influence corporate governance.

2. With the concentration of ownership and the multiplicity of stakeholders, only a 'widened' corporate governance can assure the alignment of various interests in the companies.

In order to attain the above objectives, a prior examination of theoretical analyses on corporate governance enables one to find out whether the analyses have any implications for the practice of corporate governance by companies receiving FDI in Cameroon. Furthermore, it is necessary to show that if corporate governance influences in a positive way the behavior of managers when the capital of the company is dispersed, this management by value must adapt to these host companies having a high ownership concentration.

\section{Theoretical Analysis of Corporate Governance and Their Practical Implication for Companies Receiving FDI in Cameroon}

With the advent of Limited companies (Ltd), many studies have focused on the distribution of power within the company. Corporate governance emerges as a result of successive works that dates back to the pioneer work of Berles and Means in 1932 which had previewed the rise to power of 'managerial' firms, i.e. firms controlled by managers and not owners. According to these authors, when the capital of a company is sufficiently dispersed, no single shareholder can exercise control on the company. Hence, the dispersion of capital enables managers to exert an "illegitimate" (Note 1) power on the inactive shareholders of the company. This incites the later to be active through the detention of a percentage of the capital that is sufficient to force managers to effectively conform to the principle of wealth creation. Thus, various analyses in this line suggests that a comparison between the decision making power of the shareholders and that of the managers should be made. These analyses encourage the concentration of ownership between few shareholders in order to reduce the illegitimate power of the managers.

There exist several levers of alignment of managers' behavior. These include putting in place financial incentives and the use of monitoring mechanisms, which are subdivided into internal audit mechanism, and external monitoring mechanisms. Corporate governance relies essentially on internal monitoring mechanisms. The following subsections justify the basis of analysis of this paper, and then examine the structure of corporate governance in companies receiving FDI in Cameroon.

\subsection{The Theoretical Basis of Corporate Governance}

Several successive works inspired by the initial work of Berles and Means are regarded today as the theoretical basis of corporate governance

The first is the managerial literature which puts forward the practices of a manager considered "deviant"; in particular, one that satisfies his own interests at the detriment of the non-influential owners (Baumol, 1959; Galbraith, 1967; Chanlat, 2003; Christensen and Laegreid, 2007; Christensen, and Al, 2008). Next is the agency theory which is presented as the theoretical basis of corporate governance. Agency theory defines a contract that binds shareholders and manager as a principal-agent relationship (Jensen and Meckling, 1976;Godard and Schatt, 2005; Anderson and Reed, 2003; Morck and Yeung, 2003). Within the framework of the contract, a manager has one objective - that of satisfying the interests of shareholders. Thus, any deviation creates a divergence of interests, leading to an agency problem. Lastly, the literature on corporate governance (Daily and Dalton, 1993; Caby and Hirigoyen, 2001; Charreaux, 2006) that encourages an internal mechanism that directs the actions of a manager. It defines elements relating to the voting rights 
of shareholders and improves the operation of the board of directors (BODs). These authors, certainly borrow from the theory of agency, but ignore its conclusions regarding limited companies controlled by financial markets. Corporate governance therefore improves the operation of limited company through assigning specific roles to managers, shareholders and BODs. In other words, corporate governance strives to guide the behavior of the various actors for a better functioning of the BODs.

The following exposes the behaviors of actors and then specify the role played by the BODs to align different behaviors based on the criteria of value creation.

\subsubsection{Actors of Corporate Governance: Shareholders and Managers}

The question of corporate governance became important with the advent of limited companies whose structure led Adam Smith to ponder on what owners would become since they seem to be simple spectators of "the management of their money by others". One can find answers to this by looking at the behaviour of managers, which varies according to whether the shareholders are influential or not.

- The behavior of the managers: The behavior of managers determines the role of corporate governance because of the place that they occupy within the process of value creation (Caby and Hirigoyen, 2001) and because of the separation of the functions of ownership and decision-making.

According to agency theory, the managers are the agents of the shareholders whose single vocation is to manage the company in the shareholders' interest (Ross, 1973 and Jensen and Meckling, 1976). However, managers and shareholders have different utility functions; each seeks to maximize its function (Ross, 1973). This leads to an agency conflict resulting from the opportunistic behavior of managers manifested in various forms. The first is growth seeking where the manager is motivated to pursue company growth (internal or external) since his income depends on it (Baker, Jensen and Murphy, 1988). The second is diversification. The managers may want to diversify risk but this may contradict the interest of shareholders (Aminud and Lev, 1981). The third is the pivotal position of managers. As representatives of shareholders and immediate superiors of the employees, manager's arbitration becomes difficult. He could be tempted to privilege the interests of employees (Arcimoles, 1995). The fourth is the rooting of managers which is a process by which managers free themselves from being monitored by shareholders (Pige, 1998).

The foregoing analysis shows that managers seem to occupy a determining position in the process of value creation. Within this framework, the role of corporate governance is to align his behaviours towards the criteria of the maximization of the shareholders and stakeholders' wealth. However, the effectiveness of the role of corporate governance depends on the power exercised by the shareholders as well as the operation of the BODs.

- The role of shareholders with large shares: Schleifer and Vishny (Note 2) justify this role by the guarantee of discipline of managers which it induces when capital is dispersed; the monitoring of managers becomes difficult and too expensive for a shareholder taken individually. One assumes therefore that, to ensure optimal monitoring that is profitable to all shareholders, only large shareholders should incurred monitoring cost. In line with this, Jensen (1993) brings out the notion of ' "active shareholders" who incurs the cost of monitoring and thus, the search for ownership concentration.

- The role of financial monitoring: Financial monitoring exists when a joint stock company is under the control "of a circle of persons who, thanks to their own share of capital or as representatives of the concentrated power of foreign ownership", are likely to influence significantly the management of the company. These representatives, which can be banks use the power conferred on them by the representative of shareholders to influence host companies on a long-term basis.

- The role of the institutional investors: Pastré (1992) defines them as "organizations whose mission is to manage funds entrusted on them in the long-term, while carrying out various investments, especially in financial markets". For Dupuy and Morin (1993), their role is to monitor the entire national productive systems, not only through shareholding, but also through a representation at the boards of directors or, the exercise of voting rights for the shareholders' account.

- The role of family monitoring: Family shareholding is recognized as a source of "active" shareholding (Allouche and Amann, 2000). For example, in Cameroon, family shareholding has an unequal economic importance and represents a major proportion of the economic fabric of the country. Its outperformance is explained by factors like confidence and family ties (Bourdieu, 2002). 


\subsubsection{The Role and Operation of the Board of Directors (BODs)}

According to Fama and Jensen (1983), the BODs play its role fully when the evaluation and ratification of long-term investment decisions and the monitoring of the performance of the major managers are under its control. The importance of these functions is also recognized by various reports on the governance of companies. These include: the Cadbury Report (United Kingdom, in 1992); Viénot I and II Reports (France, on 1995 and 1999).

Agency theorists and corporate governance theorists agree that the legal form that allows the BODs to exercise these functions is the limited company (Ltd). For Labelle and Raffournier (2001), the BODs are the backbone of corporate governance. It draws part of its specific competence from different members who are: shareholders, managers, representatives of employees, external managers, institutions, consultants, universities and state representatives.

\subsection{The Structure of Corporate Governance in Companies that Receive Foreign Direct Investments in Cameroon}

This subsection begins with an analysis of the dominant legal form that handles the problem of the distribution of power between the various actors. Thus, 60 companies receiving FDI in Cameroon are classified according to criteria that enable the structure to be highlighted. It is worth noting that these companies were chosen from a sample of 100 major companies that received the questionnaire. 40 companies were disqualified because they had a $100 \%$ foreign shareholding, or a $100 \%$ Cameroonian shareholding. The criteria for classification are: the legal form, the participation of the dominant shareholder, the nature of the shareholders, the nature of administrators and the accumulation of functions.

\subsubsection{The Legal Form of the Limited Companies}

For a company to acquire its identity, it must first of all chose an ideal legal structure which takes into account the nature of the activity, the social or tax status, the will of the partners to join and share power, and the financial contribution. In addition to the particular forms adapted to certain activities, OHADA (Organization for the Harmonization of Business Laws in Africa) company law recognizes partnerships (general partnership and limited liability partnership), limited liability companies (pluri-personnel and uni-personnel) and the limited company.

The limited company is destined to the functioning of large companies that need financial resources from a large number of investors who can be persons, commercial companies or groups of companies. It is consubstantial with corporate governance. This is not the case with other legal forms. An elected associated council combined into BODs, chaired by a President and assisted by one or several Chief Executive Officers manages a limited company, or still, it can be managed by a Directory which functions under the control of a Supervisory board. Its accounts are verified by statutory auditors. This paper does not treat one-man enterprises and the uni-personnel limited company legal forms in which owner's endowment is merged into the company and which does not face similar problems of governance.

According to the form described above, the limited company is the dominant legal form, accounting for $97 \%$ of the companies in the sample while $3 \%$ represents others (see annex I, Figure 1). The preponderance of Limited Companies is justified by the legislator's concern about conformity to the exigencies of the Anglo-Saxon corporate governance. In addition, its development on a broad scale is a challenge since it constitutes the principal technique that attracts foreign investors and realizes ownership concentration (Ngoungo, 2007). This result brings forth an important question concerning the level of power that Limited Companies confer to the dominant shareholder

\subsubsection{The Level of Power conferred to the Dominant Shareholder}

The power of the dominant shareholder depends on his participation, that is, the amount of capital he holds. According to Demsetz (1993), Shleifer and Vishny (1986) and Agrawal and Mandelker (1990), a high concentration of ownership in the hands of a shareholder gives him the power to effectively monitor managers and then incurring the monitoring cost. However, the need for concentration is felt most when the ownership is highly dispersed at the start which gives an opportunity of relaxed monitoring mechanism. Within the threshold of the participation of the dominant shareholder, one can distinguish the companies known as "managerial" from those known as "controlled". On this basis, we classify the companies based on the framework proposed by Berle and Means (1932) and then adapted it to our study. Thus,

- For more than a $50 \%$ ownership concentration, the dominant shareholder has the interest to monitor because the fraction of the capital enables him to finance monitoring cost and to acquire the value created.

- From 25 to $50 \%$ ownership concentration, there is the presumption of monitoring by the shareholder. This fraction is sufficient to assure the monitoring of managers. However, its efficiency will depend on the activism of the shareholder and their personal interest.

- From 10 to $25 \%$ ownership shareholding, there is a control known as "indefinite ". The power of the managers and that of the shareholders seem to neutralize. 
- From 5 to $10 \%$ ownership shareholding, there is the presumption of manager's control. The manager exercises an influential power on the shareholders.

- For less than $5 \%$ ownership shareholding, capital is completely dispersed. The managers exercise a high and "illegitimate" power on the inactive shareholders. This creates a need for ownership concentration to reduce excess power of the managers.

According to the above classification, managerial firms are few (not up to 5\%) whereas, more than 8 companies out of 10 have an ownership shareholding of more than $25 \%$. More precisely, the presumption of control by the shareholder counts for $23 \%$ and the shareholder control is estimated at $62 \%$ (annex I, Figure 2). One can conclude that there is a predominance of companies controlled by shareholders, i.e., concentrating more than $50 \%$ of ownership in a few hands. However, the power of the shareholder over the manager can also depend on the nature of the dominant shareholder

\subsubsection{The Nature of the Dominant Shareholder}

A study of the nature of the major shareholder enables one to know who is monitoring; is it the individual shareholder, institutional shareholder, foreign shareholder, family shareholder, or employee shareholder, manager shareholder or the state. Classifying companies according to the nature of the dominant shareholder reveals that more than half of the companies $(60 \%)$ are controlled by foreign investors (annex I, Figure3). This is the common trend in Cameroon for some years now, especially with the State's disengagement in the production of goods and services through the privatization of enterprises. This foreign influence can also be observed by examining the structure of the BODs of these companies.

\subsubsection{The Structure of the Board of Directors (BODs)}

The study of the structure of the BODs is based on its composition, its size, the dichotomy between internal and external directors and the representation of the other stakeholders, i.e. employees and other minority groups. Concerning the composition, one of the specificities of limited companies in Cameroon is that it can be managed either by a general administrator, shareholder or not, especially when the number of its members is lower than or equal to three (article 494 of the OHADA Company Law), or by a BODs. In all cases, administrators and commissioner of police take charge of internal auditing (article 707 of OHADA Company Law). According to Cameroonian Law of July 24, 1867 on Commercial Companies, BODs is a creation of practice, made up of at least three members at and twelve members at most. However, if the majority of the members are shareholders, the law allows the representation of non-shareholder members, for example, employees.

Concerning the composition and the separation of functions in the companies sampled, the BODs tend to be composed primarily of shareholder representatives. However, the law admits that "... if the majority of the members are shareholders, it is allowed that within the limit of the third of its members, non shareholders are allowed to be board members " (OHADA Company Law). In Cameroon, shareholders occupy $94 \%$ of the seats of the council (Annex I, Figure4). This result shows that, shareholders exercise their voting rights fully. On the contrarily, stakeholders are lowly represented, pushing one to think of corporate governance which is not sufficiently widened.

Current debate on corporate governance has however shifted from the representation of shareholders in the BODs to the representation of all stakeholders, independence of BODs, and the separation of function of Chief Executive Officer (CEO). Our results show that $83 \%$ of companies separate the function of the president of the BODs from that of the General Manager. Separation of functions is thus the rule in these companies and can be regarded as a positive factor of corporate governance insofar as managerial discretion is reduced and the monitoring of manager efficient (Caby and Hirigoyen, 2001).

To summarize, the analysis of the structure of corporate governance of companies receiving FDI in Cameroon reveals that there is a concentration of ownership and an effective presence of influential shareholders (foreign shareholders). These factors constitute the cornerstone of corporate governance and are considered as basic elements of efficient system of control (Charreaux, 2006). However, because of the specific character of the companies in Cameroon, it is necessary to verify whether the elements favour the alignment of interest and the growth of individual return. This is handled in the second part of the work which is essentially empirical.

\section{Concentration of Ownership and the Divergence of the Interests in Cameroonian Companies}

The objective of this second part is to show that the Cameroonian companies receiving FDIs seem to be a contractual link of multiple interests. It appears that, considering all these interests when ownership is highly concentrated reduces agency conflicts and motivates stakeholders in generally. One may presume that if the number of stakeholders of the host company increases, the interests to be satisfied also increases. If this is the case, the host company can be 
understood as a legal friction based on property rights within which different actors have a specific utility function. These functions are linked between them by a multitude of contracts. For example, the contract which binds shareholders (principals) and acting managers (agents) takes a particular character as far as it brings in the national and foreign shareholders, on one hand, the acting national and foreign managers, and the national and foreign stakeholders, on the other hand. The difficulty faced by management in such a case would result from the necessity to satisfy at the same time national and foreign interests. Consequently, "widened" governance can be more successful than specific "shareholder" governance. To demonstrate this, a methodological justification is necessary (sub-section 3.1) before showing why these companies are a contractual link of multiple interests which requires specific conflict resolution mechanisms (sub-section 3.2).

\subsection{Methodology}

The article postulates that ownership concentration determines the performance of corporate governance through its influence on the alignment of interests and the reduction of the agency conflicts. This is a causal explanatory problem. Such a problem thus requires an appropriate quantitative methodology. Given the causal nature of the problem, primary data was collected from a sample of companies by way of a questionnaire.

Method of analysis: The design of the questionnaire was based on the principle of corporate governance in OECD countries and other reports notably Viénot 1 and 2 reports (France), Cadbury and Granbury reports (United Kingdom) and the codes of practices of corporate governance.

The study concerned a total population of 100 large companies receiving FDIs in Cameroon. However, the sample was reduced to 60 companies to eliminate those whose owners were entirely foreign (100\%) or entirely Cameroonians $(100 \%)$. The aim was to have a sample of companies that are owned by both foreign and national shareholders. It is assumed that ownership concentration associated with international diversification of property can be one of the important sources of divergence of interests between shareholders and contributors of human capital.

Taking into consideration indicators of all variables, the questionnaire contained 4 key topics of corporate governance. These are: firstly, property structure (8 questions) which provides information on the geography of capital, especially, its shareholding composition, its level of concentration, the origin of the dominant shareholder and others; secondly, the composition of the BODs (9 questions) which constitutes questions on a general discussion on the composition and the operation of the BODs; thirdly, remuneration policy for contributors of human capital (10 questions) which comprises questions on various forms of remuneration of the managers and employees, especially those forms that enables an alignment of their interest with those of owners; and fourthly, agency conflicts (5 questions) made up of questions that expose the state of the conflicts in host companies.

The analysis of the data is done in two stages: a factorial analysis and a discriminant analysis. It was necessary to proceed with a classification of data in order to regroup data. This justifies the use of factorial analysis which enables one to obtain general factors or key dimensions (Donada and Mbengue, 2003). These general factors serve as explanatory factors in the discriminant analysis which was realizes using the SPSS 10.0 software. Thus, 5 groups of companies were obtained. These groups are: companies with dispersed ownership concentration (at less than 5\%); companies with little ownership concentration (5 to 10\%); companies with low ownership concentration (10 to $25 \%$ ); companies with the average ownership concentration (25 to $50 \%$ ) and companies with a high ownership concentration (at the level of more than $50 \%$ ).

\subsection{Presentation and Interpretation of Results}

The use of factorial analysis in the analysis of Companies in Cameroon was justified by the results of two tests: the tests of sphericity of Bartlett (KMO) and the cree-test of Cattel. The KMO test gives an index of 0.746 which is higher than 0.50 (minimum allowed to continue factorial analysis) and the Chi-2 obtained from this test is sufficiently high $(680,948)$ and thus significant (see annex II, table 1). For the cree-test of Cattel, insofar as the starting point of the analysis is the matrix of correlations, the common rule (of Kaiser) is to retain the factors corresponding to eigenvalues higher than a unit. Thus, six factorial axes that were selected explain $73.16 \%$ of the original variance, determined at the point of inflection of the curve of Cattel's scree-test (see annex, Figure7). Three principal functions are then extracted from these six factorial axes at group Centroids (see annex II, table 2). These functions enable one to distinguish between the groups of companies obtained. Hence, through the first discriminant function, it appears that the group of companies with low ownership concentration is different from companies with high ownership concentration $(-0.353$ against 2.848 respectively). For the second function, companies with low ownership concentration are evaluated most favourable (with an absolute value of 2.723) whereas companies with average ownership concentration are few $(0.020)$. 
According to the third function companies with average ownership concentration are favourably evaluated (0.454) more than companies with high ownership concentration (0.07).

The validity of the discriminant analysis is done through the Box's $M$ test. According to this test $M$ must have a sufficiently high value and the significance of the F-test must converge towards 0 . This condition is verified. $\mathrm{M}$ equals 81.381, which is sufficiently high, and $\mathrm{F}$ value is equal to 0.37 which tends towards 0 (see annex II, table 3 ). One can then carry out a descriptive analysis to appreciate the results obtained.

The results reveal that companies with dispersed ownership are very rare. Companies with little and low ownership concentration have diametrically distinct characteristics from those with high ownership concentration. On the other hand, companies with average ownership concentration have characteristics that are closer to companies with low ownership concentration and those with high ownership concentration (see annex II, tables 4, 5, 6). Finally, companies with high ownership concentration have characteristics that are judged unfavorable for good corporate governance. They are characterized by high agency conflicts, low return, low representation of employees and foreign administrators in the BODs (see annex II, tables 4, 5, 6).

After presenting the characteristics of companies and their governance, we want to show that with numerous stakeholders and numerous interests to satisfy; only "widened" corporate governance is capable to ensure the alignment of all interests.

\section{The Companies Receiving FDI in Cameroon: The Satisfaction of the Multiple Interests}

The analysis of the various interests to be satisfied within the companies reveals that these interests can be numerous and is a function of the number of stakeholders involved in the activities of the company. If such is the case, the organization of the Cameroonian companies receiving FDIs seems to be specific because of the many stakes characterized by multiple conflicts that arise from the division of wealth created. For example, a FDI operation can be followed by a demand for higher wages especially when their contribution (know-how) cannot be ignored in the process of value creation. For the contrary case, they can conflict with influential shareholders. This reflection can extend to all the stakeholders, especially if each would want, at all costs, to create conditions favourable for obtaining a rent.

Caby and Hirigoyen (2001) consider that when stakeholders are numerous and demanding, their consideration is an imperative. Thus, 'shareholder governance' should be replaced by 'widened governance' which should take into consideration interest of shareholders as well as those of investors of human capital and stakeholders. Clarkson (1995) considers stakeholders as persons who incur risk with regard to the product of the activities of the company. He separates the primary stakeholders whose presence is essential for the survival of the company (shareholders, customers, community, creditors, suppliers, the government, employees, etc.) from secondary stakeholders who have no transaction with the company (special interest groups, media, etc) (Note 3). Their engagement in the company introduces an ex-post risk in the case where they can be exempted from rent distribution (Note 4). For this reason, Drew, Ruf and Brown (2001) distinguish voluntary stakeholders (shareholders, customers, community, creditors, suppliers, employees, etc.) and involuntary stakeholders (community, environment, the company, etc). With such a categorization of the fascinating parts and considering the international diversification of property, it can be noticed that the number of interests to satisfy is higher in companies receiving FDI than in others. Thus, the interests to satisfy in such a company will be constituted by those of foreigners on the one hand, and nationals on the other hand. This distinction justifies itself insofar as foreigners do not have the same objectives as nationals. This explosion of interests is imperative for all the stakeholders (leader, customers, suppliers, employees, etc). Therefore, the companies receiving FDI have more interests to be satisfied than others. This appears as a contractual link, which can lead to a multitude of agency conflicts.

\subsection{A Multitude of Conflicts in the Companies Receiving Foreign Direct Investments in Cameroon}

Several conflicts not explicitly captured by agency theory can be found in companies receiving FDIs due to the large number of stakeholders. Let us examine the particular case of shareholders/managers conflicts.

The shareholders/managers conflicts have a particular character in such a company if the manager of the company (just as in others) tries to increase the benefit drawn from his position. He will want, for example, to carry out risky diversifications in order to increase the size of the company (because their prestige depends on it), or to limit the initiative of the subordinates by centralizing all significant decisions (Note 5). For Gardes (2005), this behaviour depends on the proportion of the capital held by the manager. Thus, it can be imagined that if the manager participate in the capital of the company, he will be less opportunist. The larger his share, the more he would be interested in maximizing the value of the company.

Besides, the shareholders/manager conflict arises when each shareholder holds only a small fraction of the capital of the company, each letting the others take care of the control of managers taking into account the cost associated with such a 
task (free riding). No agent would in this case be motivated to assure the legitimacy of the decisions of the manager or ensure the protection of shareholders. However, the protection of the shareholders does not exclude that of managers who must also control the counterpart remunerating his managerial capital in view of implementing value-creating specific investments (Charreaux, 1997). From this point of view, the manager of the company receiving FDI is a stakeholder among the others. His protection depends on the survival of the coalition of interests in the company. According to a recent study by Ngoungo (2007), companies receiving FDIs in Cameroon face at least 15 types of conflicts, instead of 3 types frequently met in other companies as shown by the diagram below.

$<$ Figure 8 about here $>$

Arrows symbolize the conflicts between two groups of actors. (FS) represents foreign shareholders, (FM) foreign managers, (NM) national managers, (NS) national shareholders, (FE) foreign employees and (NE) national employees. This diversity of interests in the companies receiving FDIs justifies the necessity of using specific conflict resolution mechanisms shown in the following subsection.

\subsection{The Mechanisms of Conflict Resolution at the Level of Ccompanies Receiving FDI in Cameroon}

For certain theorists (in particular Cobbaut and Lenoble, 2003), the participation of the manager in the capital of the company he manages is considered as a strategy of rooting. For others, rooting is not inevitably harmful for the shareholders. Castanias and Helfat (1992) and Carvey and Swan (1994) estimate that rooting that is compatible with efficiency is characterized by rent creation by the manager who is motivated to develop his managerial capacity through taking strategic decisions. For Desbrieres (1997), manager shareholding contributes to his rooting. This motivates him to play a determining role in corporate governance and participate in setting up monitoring mechanism instead of undergoing them only.

Thus, widening corporate governance to acting managers would be effective especially when the ownership is highly concentrated at the start and when the conflicts between shareholders and acting managers are very high. This goes in line with Caby and Hirigoyen (2007) who propose the replacement of the primacy of stakeholders to the primacy of shareholders in order to motivate those who bring in human capital.

One can consider that the widening of the capital of companies receiving FDIs in Cameroon to active managers can contribute to motivate them and especially to align their interests with those of shareholders. This is one of the ways proposed for shareholders-manager conflict resolution in such companies. Thus, agency conflict resolution can arise from a passage from an essentially 'shareholder' corporate governance to a 'partnership' or 'widened' corporate governance.

As an illustration, let us consider that at the first period time zero (To) the corporate governance known as shareholder corporate governance (Gs) is applied, its effectiveness depends on the presence of influential shareholders (according to the various theories mentioned above). In practice, it appears that the need for (Gs) is felt most when the capital is dispersed, because it gives the acting manager an illegitimate power which he exerts on the non-influential shareholders (Charreaux, 1997). One of the strategies can consist in withdrawing some of the excess power held the manager and redistributing it to shareholders through motivating the later to increase their shares in order to become influential and thus becoming major actors of corporate governance. This strategy will resurrect the dormant shareholder who would then be ready to engage time and financial resources for monitoring acting managers.

Nevertheless, when the part of the dominant shareholder begins to reach proportions higher than $50 \%$, conflict with stakeholders arises because the stakeholders will consider that the total value created is expropriated by the influential shareholder. When such a conflict arises, its resolution consists of applying an inverse strategy in which certain stakeholders (especially managers and employees) are encouraged to participate in the ownership of the company. This implies that there is an initial widening of capital, and then the widening of corporate governance to stakeholders. Governance thus becomes partnership corporate governance (Gp) whose principal objective is to satisfy the interests of both shareholders and all stakeholders. This strategy facilitates social cohesion and the alignment of interests (see annex I, Figure 6).

\section{Conclusion}

Undoubtedly, if we consider the various control theories, the control by shareholders is increasing in the companies receiving FDIs in Cameroon, while that of manager seems to decline. The novelty lies in the emergence of foreign shareholder power who takes advantage of the incentives for attracting foreign investors setup in these companies. These FDIs takes two forms, FDIs investing in equity in existing companies in Cameroon and the FDIs creating subsidiaries of $100 \%$ foreigners. 
Examining the practice of corporate governance of 60 companies receiving FDIs in Cameroon, reveals that almost all of them are limited companies (97\%) and more than $60 \%$ of these companies have an ownership concentration of more than $50 \%$ in the hands of foreign shareholder. On the other hand, the boards of directors of these companies are dominated by shareholders or their representatives.

These results also reveal that if the characteristics of corporate governance practiced present certain favourable elements (especially ownership concentration and the presence of influential shareholders), by contrast, these elements favour the satisfaction of the interests of the shareholders only.

This article therefore suggests partnership or widened corporate governance to all stakeholders, requiring the participation of the acting managers and employees in the capital; which favors the alignment of their interests with those of shareholders. The reasons for their participation in the capital are to decrease the abuse of power by the shareholders that could arise from a high ownership concentration and to reduce thereafter conflicts arising from the risk of despoliation of stakeholder by influential shareholders. This constitutes a strategy for reducing agency conflicts through a convergence of interests that participation induces. As underlines by Prowse (1994), the inertia of corporate governance is important more than that of finance and convergence; if there is convergence, it will affect the elements of the system which evolve in an autonomous way on a long-term basis.

We can then end with the Stiglitz (2002) ideas which states that to act in the direction of general interest would imply to act in the direction of the shareholders.

\section{References}

Allouche, J. \& Amann, B. (2000). “ L'entreprise Familiale : un état de l'art”, Finance Contrôle Stratégie, Vol. 3, n1, Mars 2000, pp. 33-79.

Amhud, Y. \& Lev, B. (1981). "Risk Reduction as a Managerial Motive for Conglomerate Mergers", Bell Journal of Economics.

Anderson, R., Mansi, S. \& Reeb, D. (2003). "Founding family ownership and the agency cost of debt", Journal of Financial Economics, 68, pp.263-285. http://dx.doi.org/10.1016/S0304-405X(03)00067-9

Aoki, M., Gustafsson, B. \& Williamson, O. E. (1990). The Firm as a Nexus of Treaties, Sage

Bauer, M. \& Bertin-Mourot, B. (1990). Les 200, en France et en Allemagne, CNRS.

Baysinger, B. \& Butler, H. (1985). "Corporate Governance and the Board of Directors: Performance Effects of Changes in Board Composition", Journal of Law and Economics, 1.

Caby, J. \& Hirigoyen, G. (2001). "La création de la valeur”, Collection Connaissance de la Gestion, Economica.

Chanlat, J. F. (2003). "Le managérialisme et l'éthique du bien commun: la question de la motivation au travail dans les services publics"; In: T. Duvillier, J.-L. Genard et A. Piraux; La motivation au travail dans les services publics; Paris, L'Harmattan (2003); 51-64

Charreaux, G. (2002). "Variation sur le thème : A la recherche de nouvelles fondations pour la finance et la gouvernance d'entreprise", Finance Contrôle Stratégie, vol. 5, p.5-68.

Charreaux, G. \& Wirtz, P. (2006). Gouvernance des Entreprises, nouvelles perspectives, Economica, Paris.

Cobbaut, R. \& Lenoble, J. (2003). Corporate Governace An Institutionnal Approach, Kluwer Law International Den Hague.

Christensen, T. \& Laegreid, P. (2007). "Transcending New Public Management: the transformation of public sector reform"; Aldershot, Ashgate Publishing Ltd

Christensen, T. A. et al. (2008). "Beyond New Public Management: Agencification and Regulation Reform in Norway"; Financial Accountability \& Management; 24 (1): 15-30. http://dx.doi.org/10.1111/j.1468-0408.2008.00441.x

FTSE ISS Corporate Governance Rating and Index Series. (2004). Measuring the Impact of Corporate Governance on Global Portfolios.

Hirigoyen, G. (2002). "Le gouvernement des entreprises familiales", in La gestion des entreprises familiales, sous la direction de Caby J. et Hirigoyen G, Economica,.

Harti, G. (2000). Le gouvernement d'entreprise en Europe : pratiques des grands groups allemands, français et britanniques, les Cahiers de la recherche, Ecole Supérieure de Commerce de Rouen. 
Jensen, M. (1988). "The Distribution of Power among Corporate Managers, Shareholders and Directors", Journal of Finance, 48.3.

Jensen, M. C. \& Meckling, W. H. (1976). "Theory of the Firm, Managerial Behavior, Agency Costs and Ownership Structure", Journal of Financial Economics, 3.

Labelle, R. \& Raffournier, B. (2001). "Les conseils d'administration: convergence des pratiques au niveau international ", Problèmes Economiques, n.2700.

Moody's. (1997). “La notation Moody's”. mode d'emploi.

Morck, R. \& Yeung, B. (2003). "Agency problems in large family groups”, Entrepreneurship Theory and Practice, vol. 27, pp. 367- 382. http://dx.doi.org/10.1111/1540-8520.t01-1-00015

Ngougo, D. (2007). Les Investissements Directs Etrangers et la performance de la gouvernance des entreprises camerounaises d'accueil, Thèse, 384 pages.

Prowse, S. (1994). "Corporate Governace : Comparaison Internationale”, Revue d'Economie financière, 31.

Standard \& Poor's. (2004), Standard et Poor's Corporate Governance Scores and Evaluations: Criteria, Methodology and Definitions, Standard \& Poor's Governance services, New York

Stiglitz, J. (2002). La grande désillusion, Fayard.

\section{Notes}

Note 1. Rooting can be perceived as the fruit of an illegitimate power if it makes it possible for management to increase its power next to that of the partners beyond the level of the performance of the company

Note 2. Schleifer, A. \& Vishny, R. (1986). "Large shareholders and corporate control", Journal of Political Economy, Vol. 94, n3.

Note 3. For a thorough vision of the identification of the stakeholders and their weight, one can refer to Mitchell, R. K., Agle, B. R. and Wood, D. J. (1997). They distinguish in particular three information of identification: capacity, legitimacy and urgency.

Note 4. These rents result from the reduction of the transaction costs induced by setting up of long-term relations with the stakeholders. This ameliorates the value of the firm (Tiras. S.L., B Ruf \& Brown. R.M. 1997).

Note 5. These criticisms are taken again by J.K. Galbraith (1967) whose work describes the existence of a techno-structure company that prevents the creation of value

Table 1. The test of Bartlett and the KMO index

\begin{tabular}{|c|c|c|}
\hline Kaiser-Meyer-Olkin Measure of Sampling Adequacy. & \multicolumn{2}{|c|}{0,746} \\
\hline Bartlett's Test of Sphericity & Approx. Chi-Square & 680,948 \\
\hline & df & 190 \\
\hline & Sig. & 0,000 \\
\hline
\end{tabular}

Source: Our statistical output using SPSS 10 software.

Table 2. Functions at Group Centroids

\begin{tabular}{|c|c|c|c|}
\hline & \multicolumn{3}{|c|}{ Function } \\
\hline Classification of companies according to their thresholds of ownership concentration & 1 & 2 & 3 \\
\hline Companies with high concentrated shareholding (more than 50\%) & -.353 & -.136 & 0.079715 \\
\hline Companies with average concentrated shareholding (from 25-50 \%) & .307 & 0.02031982 & -.454 \\
\hline Companies with little concentrated shareholding (from 10-25\%) & .764 & .851 & .221 \\
\hline Companies with low concentrated shareholding (from 5-10\%) & 2.848 & -2.723 & .430 \\
\hline
\end{tabular}

Source: Our statistical output with the help of the SPSS 10.0 software 
Table 3. Box's M Test Results

\begin{tabular}{|c|c|c|}
\hline \multicolumn{2}{|c|}{ Box's M } & 81.381 \\
\hline Approx & 1.431 \\
\hline $\mathrm{df1}$ & 42 \\
\hline $\mathrm{df} 2$ & 1823.273 \\
\hline Sig & .037 \\
\hline
\end{tabular}

Table 4. Characteristic of companies with low concentrated shareholding

\begin{tabular}{|c|c|c|}
\hline Nature of the major shareholder & Number & $\underline{0}$ \\
\hline Foreign shareholder & 3 & 27.00 \\
\hline Financial shareholder representative & 3 & 27.00 \\
\hline Other private Cameroonians & 5 & 46.00 \\
\hline Total & 11 & 100.00 \\
\hline The Origin of the acting manager & Number & $\%$ \\
\hline Foreign manager & - & - \\
\hline Manager representing the state & 2 & 18.00 \\
\hline Private Cameroonian manager & 9 & 82.00 \\
\hline Total & 11 & 100.00 \\
\hline Job creation & Number & $\underline{\%}$ \\
\hline Yes & 8 & 73.00 \\
\hline No & 3 & 27.00 \\
\hline Total & 11 & 100.00 \\
\hline Turnover of the acting managers & Number & $\%$ \\
\hline Yes & 5 & $4 \overline{5.00}$ \\
\hline No & 6 & 55.00 \\
\hline Total & 11 & 100.00 \\
\hline Job suppression & $\underline{\text { Number }}$ & $\underline{\%}$ \\
\hline Yes & 1 & 09.00 \\
\hline No & 10 & 91.00 \\
\hline Total & 11 & 100.00 \\
\hline Agency Conflict & $\underline{\text { Number }}$ & $\underline{\%}$ \\
\hline Low & 10 & 91.00 \\
\hline High & - & - \\
\hline Very high & 1 & 09.00 \\
\hline Total & 11 & 100.00 \\
\hline Appreciation of return & Number & $\underline{\%}$ \\
\hline low & 1 & 09.00 \\
\hline average & 1 & 09.00 \\
\hline good & 8 & 73.00 \\
\hline Excellent & 1 & 09.00 \\
\hline Total & 11 & 100.00 \\
\hline
\end{tabular}


Table 5. Characteristic of host companies receiving FDI with average concentrated shareholding

\begin{tabular}{|c|c|c|}
\hline Nature of the major shareholder & Number & $\%$ \\
Foreign shareholder & 10 & 10.00 \\
Financial shareholder representative & 2 & 20.00 \\
Other private Cameroonians & 1 & 10.00 \\
Total & 09 & 100.00 \\
The Origin of the acting manager & Number & $\%$ \\
Foreign manager & 5 & 50.00 \\
Manager representing the state & 2 & 20.00 \\
Private Cameroonian manager & 3 & 30.00 \\
Total & 09 & 100.00 \\
Job creation & number & $\%$ \\
Yes & 1 & 10.00 \\
No & 9 & 90.00 \\
Total & 09 & 100.00 \\
Yes & Effectif & $\%$ \\
No & 9 & 90.00 \\
Total & 1 & 10.00 \\
Job suppression & 09 & 100.00 \\
Yes & Number & $\%$ \\
No & 4 & 40.00 \\
Total & 6 & 60.00 \\
Agency Conflict & 09 & 100.00 \\
Low & Number & $\%$ \\
High & 5 & 50.00 \\
Very high & 3 & 30.00 \\
Total & 2 & 20.00 \\
Appreciation of return & 09 & 100.00 \\
low & Number & $\%$ \\
average & 4 & 40.00 \\
good & 3 & 30.00 \\
Excellent & 2 & 20.00 \\
Total & 1 & 10.00 \\
& 09 & 100.00 \\
\hline &
\end{tabular}


Table 6. Characteristics companies receiving FDI with high concentrated shareholding

\begin{tabular}{|c|c|c|c|}
\hline Nature of the major shareholder & & Number & $\underline{\%}$ \\
\hline Foreign shareholder & & 29 & $\overline{74} .00$ \\
\hline Financial shareholder representative & & 1 & 03.00 \\
\hline Institutional shareholder representative & & 5 & 13.00 \\
\hline Other private Cameroonians & & 4 & 10.00 \\
\hline Total & & 36 & 100.00 \\
\hline The Origin of the acting manager & & Number & $\%$ \\
\hline Foreign manager & & 33 & $\overline{84} .00$ \\
\hline Manager representing the state & & 1 & 03.00 \\
\hline Private Cameroonian manager & & 5 & 13.00 \\
\hline Total & & 36 & 100.00 \\
\hline Job creation & & Number & $\%$ \\
\hline$\overline{\text { Yes }}$ & & $\overline{16}$ & $\overline{41.00}$ \\
\hline No & & 23 & 59.00 \\
\hline Total & & 36 & 100.00 \\
\hline Turnover of the acting managers & & Number & $\% \underline{0}$ \\
\hline$\overline{\text { Yes }}$ & & 23 & $\overline{59} .00$ \\
\hline No & & 16 & 41.00 \\
\hline Total & & 36 & 100.00 \\
\hline Job suppression & & Number & $\%$ \\
\hline Yes & & 27 & $\overline{69} .00$ \\
\hline No & & 12 & 31.00 \\
\hline Total & & 36 & 100.00 \\
\hline Agency Conflict & & Number & $\%$ \\
\hline Low & & 10 & $\overline{26} .00$ \\
\hline High & & 11 & 28.00 \\
\hline Very high & & 18 & 46.00 \\
\hline Total & & 36 & 100.00 \\
\hline Appreciation of return & & Number & $\underline{\%}$ \\
\hline low & & 20 & $\overline{51.00}$ \\
\hline average & & 7 & 18.00 \\
\hline good & & 9 & 23.00 \\
\hline Excellent & & 3 & 08.00 \\
\hline & Total & 36 & 100.00 \\
\hline
\end{tabular}

Table 7. The discriminant profile of companies receiving FDI low or little concentration of capital

\begin{tabular}{|c|c|}
\hline Variables & Discriminant profile \\
\hline Nature of major shareholder & Major shareholder is often a private Cameroonian \\
\hline Origin of acting manager & The acting manager is often a private Cameroonian \\
\hline Job creation & These companies create more jobs than others. \\
\hline Turnover of managers & They face few problems when acting manager change hands \\
\hline Job suppression & There are less shareholder/employee conflicts in the companies \\
concerned.
\end{tabular}


Table 8. The discriminant profile of host companies with average concentration of ownership

\begin{tabular}{|c|c|}
\hline Variables & Discriminant profil \\
\hline $\begin{array}{l}\text { Nature of major } \\
\text { shareholder }\end{array}$ & Major shareholder is often a private foreigner \\
\hline $\begin{array}{l}\text { Origin of acting } \\
\text { manager }\end{array}$ & Acting managers are either a private Cameroonian or foreigner \\
\hline Job creation & $\begin{array}{l}\text { These companies have interest in employee problems just as FDI companies of } \\
\text { concentrated ownership }\end{array}$ \\
\hline Turnover of managers & They process turnover as FDI companies of highly concerntrated ownership \\
\hline Job suppression & Jobs are preserved just as in FDI companies of lowly ownership concentration \\
\hline Agency conflict & There are average agency conflicts \\
\hline Appreciation of returns & Returns are generally on average \\
\hline
\end{tabular}

Table 9. The discriminant profile of FDI companies of high concertrated capital

\begin{tabular}{|c|c|}
\hline Les variables & Profil discriminant \\
\hline Nature of major shareholder & Major shareholder is often a foreign shareholder \\
\hline Origin of acting manager & Acting manager is often a foreigner \\
\hline Job creation & These enterprises hardly create jobs \\
\hline Turnover of managers & Turnover is frequent \\
\hline Job suppression & These companies sometimes have job suppression \\
\hline Existence of an external administrators & External administrators are rare in the board \\
\hline Existence of administrators who are wage earners & Low level of employee representatives in the BODs \\
\hline Agency conflicts & Agency conflicts is very high in these companies \\
\hline Appreeciation of returns & Returns are generally low \\
\hline
\end{tabular}

Table $10 \mathrm{du}$ Total Variance Explained

\begin{tabular}{|c|c|c|c|c|c|c|}
\hline & $\begin{array}{c}\text { Initial } \\
\text { Eigenvalues }\end{array}$ & & & $\begin{array}{r}\text { Rotation Sums of } \\
\text { Squared Loadings }\end{array}$ & & \\
\hline Component & Total & \% of & Cumulative & Total & \% of \\
Variance & $\%$ & & Cumulative \\
$\%$
\end{tabular}




\begin{tabular}{|c|c|c|c|l|l|l|}
\hline 17 &, 163 &, 816 & 98,518 & & & \\
\hline 18 &, 153 &, 764 & 99,282 & & & \\
\hline 19 &, 121 &, 605 & 99,887 & & & \\
\hline 20 & $2,260 \mathrm{E}-02$ &, 113 & 100,000 & & & \\
\hline
\end{tabular}

Extraction Method: Principal Component Analysis.

Table 11 - Rotated Component Matrix

\begin{tabular}{|l|l|l|l|l|l|l|}
\hline \multicolumn{7}{|l|}{ Components } \\
\hline & F1 & F2 & F3 & F4 & F5 & F6 \\
\hline Ppal.Act.Etr. ? &, 920 & $1,362 \mathrm{E}-02$ & $6,325^{\mathrm{E}}-02$ & $3,948 \mathrm{E}-02$ & $3,702 \mathrm{E}-02$ & $1,348 \mathrm{E}-02$ \\
\hline NbrAdmEtr &, 912 & $-4,168 \mathrm{E}-02-2,766 \mathrm{E}-02$ & $-5,588 \mathrm{E}-03$ & $-1,953 \mathrm{E}-022,986 \mathrm{E}-02$ \\
\hline Tx.PartAct.Etr &, 871 & $1,476 \mathrm{E}-02$ & $5,177 \mathrm{E}-02$ & $6,065 \mathrm{E}-02$ & $4,773 \mathrm{E}-02$ & $2,511 \mathrm{E}-02$ \\
\hline Appréc.Conf.Act/Sal. &,- 740 &,- 119 &,- 386 &, 104 &,- 144 &,- 369 \\
\hline Nbr.Conf.Act/Sal. &, 737 &, 104 &, 434 &,- 105 &, 135 &, 325 \\
\hline Orig.Dirig. &, 545 &,- 485 &, 156 &, 236 &,- 105 &, 231 \\
\hline Appréc.Rendmts &, 541 &, 185 &, 447 &,- 164 &, 346 &, 355 \\
\hline Dirig.Souh.Part.K1. & $4,012 \mathrm{E}-03$ &, 846 &, 147 &, 191 & $-5,325 \mathrm{E}-02-, 124$ \\
\hline Part.Dirig.K1./Appréc. Conf.-,,127 &, 777 & $-5,605^{\mathrm{E}}-02$ & $2,563 \mathrm{E}-02$ & $6,527 \mathrm{E}-02$ &, 121 \\
\hline Appréc.Conf. Act./Dirig &,- 278 &,- 686 &,- 199 &, 273 &,- 131 & $-1,739 \mathrm{E}-02$ \\
\hline Recrut. Pers.? & $-5,104 \mathrm{E}-028,894 \mathrm{E}-02$ &,- 817 &, 161 & $3,595 \mathrm{E}-02$ & $8,972 \mathrm{E}-03$ \\
\hline Part.Sal.K1./Appréc. Conf. &, 188 &, 382 &, 536 &, 176 & $1,665 \mathrm{E}-02$ &,- 257 \\
\hline Sal.Souh. Part. K1. ? &, 161 &, 288 &, 514 &, 210 &,- 224 & $-6,532 \mathrm{E}-02$ \\
\hline Etat part. Kl. ? & $2,113 \mathrm{E}-02$ & $-3,118 \mathrm{E}-02$ & $3,364^{\mathrm{E}}-02$ &, 868 & $7,252 \mathrm{E}-02$ &, 195 \\
\hline Act. Institu.Part.K1. ? & $-7,227 \mathrm{E}-028,823 \mathrm{E}-02$ & $-2,846 \mathrm{E}-02,785$ &, 443 &,- 110 \\
\hline Act.Fin.Part.K1 ? & $-9,615 \mathrm{E}-02,123$ & $-4,027^{\mathrm{E}}-02$ &, 131 &, 793 &,- 115 \\
\hline Act.Priv.Part.K1. ? &,- 280 & $-1,121 \mathrm{E}-02,146$ &,- 388 &,- 628 & $4,060 \mathrm{E}-02$ \\
\hline Rep.Sal.CA? &,- 426 & $8,367 \mathrm{E}-02$ &,- 120 & $-4,299 \mathrm{E}-02$ &,- 509 &,- 270 \\
\hline Turnover ? &, 179 & $-4,880 \mathrm{E}-02-, 262$ & $6,282 \mathrm{E}-02$ &,- 181 &, 826 \\
\hline Réduct.Pers. ? &, 316 & $-3,199 \mathrm{E}-03,446$ &, 290 &, 199 &, 575 \\
\hline
\end{tabular}

Extraction Method: Principal Component Analysis. Rotation Method: Varimax with Kaiser Normalization. A Rotation converged in 15 iterations.

Source: Elaborated by us using the SPSS 10.0 software

Table 12. Matrix of the structure

\begin{tabular}{|c|c|c|c|c|c|}
\hline \multirow{2}{*}{\multicolumn{2}{|c|}{ Descriminant functions }} & & \multicolumn{3}{|c|}{ Function } \\
\hline & & & 1 & 2 & 3 \\
\hline BART factor score & 6 for analysis & 1 & $541 *$ & 211 &,- 349 \\
\hline BART factor score & 1 for analysis & 1 & $425^{*}$ & ,391 & 188 \\
\hline BART factor score & 5 for analysis & 1 &,- 358 & ,737* & ,389 \\
\hline BART factor score & 4 for analysis & 1 & ,166 &,$- 232 *$ & 110 \\
\hline BART factor score & 3 for analysis & 1 & ,411 &,- 128 &, $721 *$ \\
\hline BART factor score & 2 for analysis & 1 &,- 180 &,- 311 & ,444* \\
\hline
\end{tabular}

Source: The output of statistical treatment using the SPSS 10.0 software 


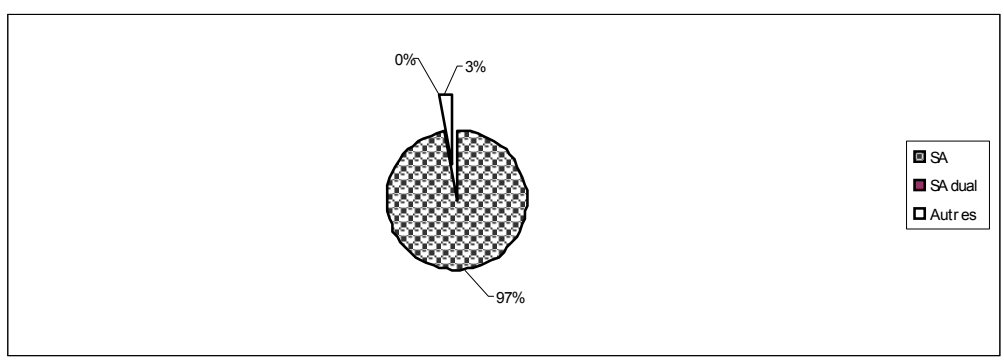

Figure 1. The legal form of the companies receiving FDI in Cameroon

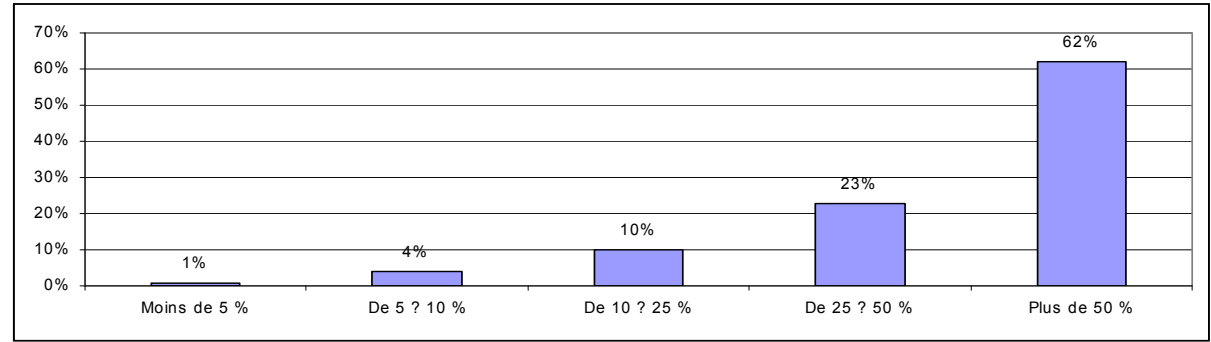

Figure 2. The participation of the first shareholder in companies receiving FDI in Cameroon

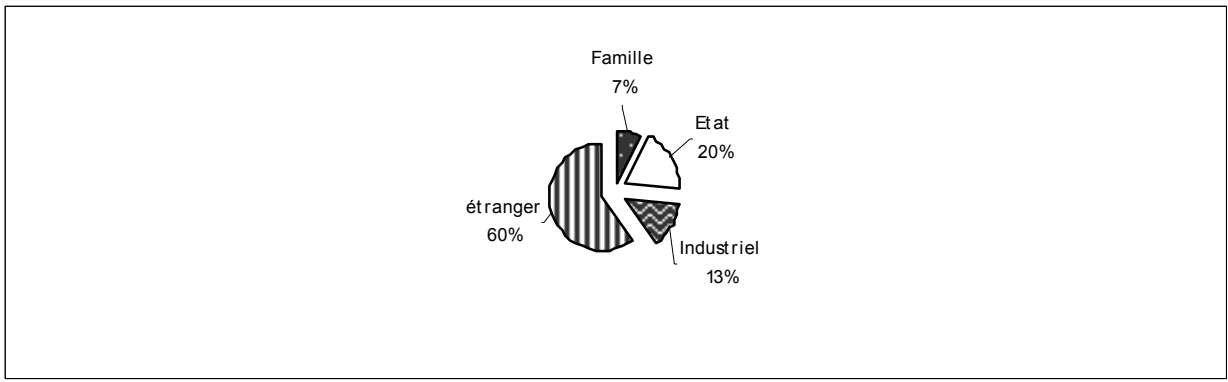

Figure 3. The nature of the major shareholder in the companies receiving FDI in Cameroon

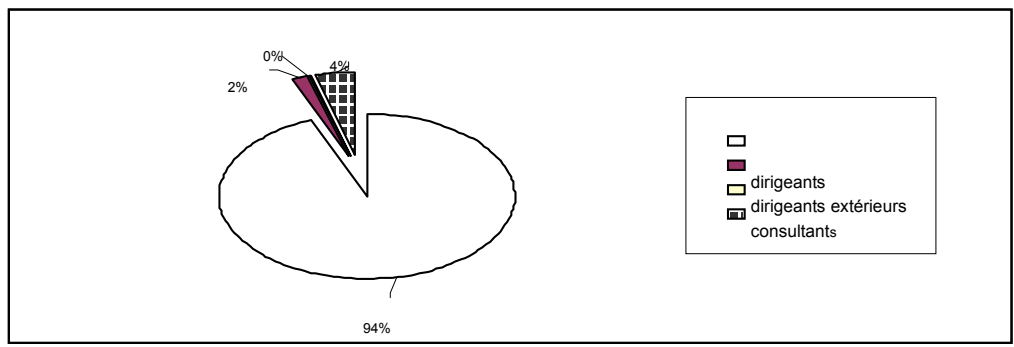

Figure 4. The composition of board of directors (BODs) of companies receiving FDI in Cameroon 


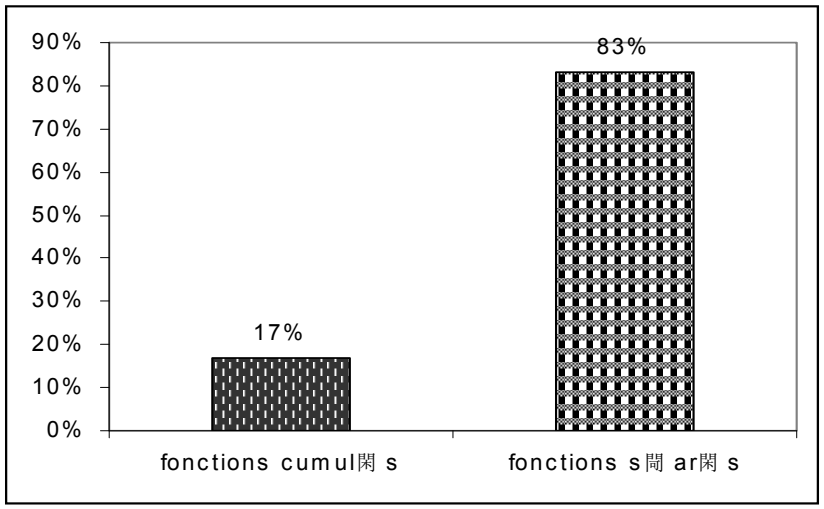

Figure 5. The separation of the function of the president of the board and the general director of the companies receiving FDI in Cameroon

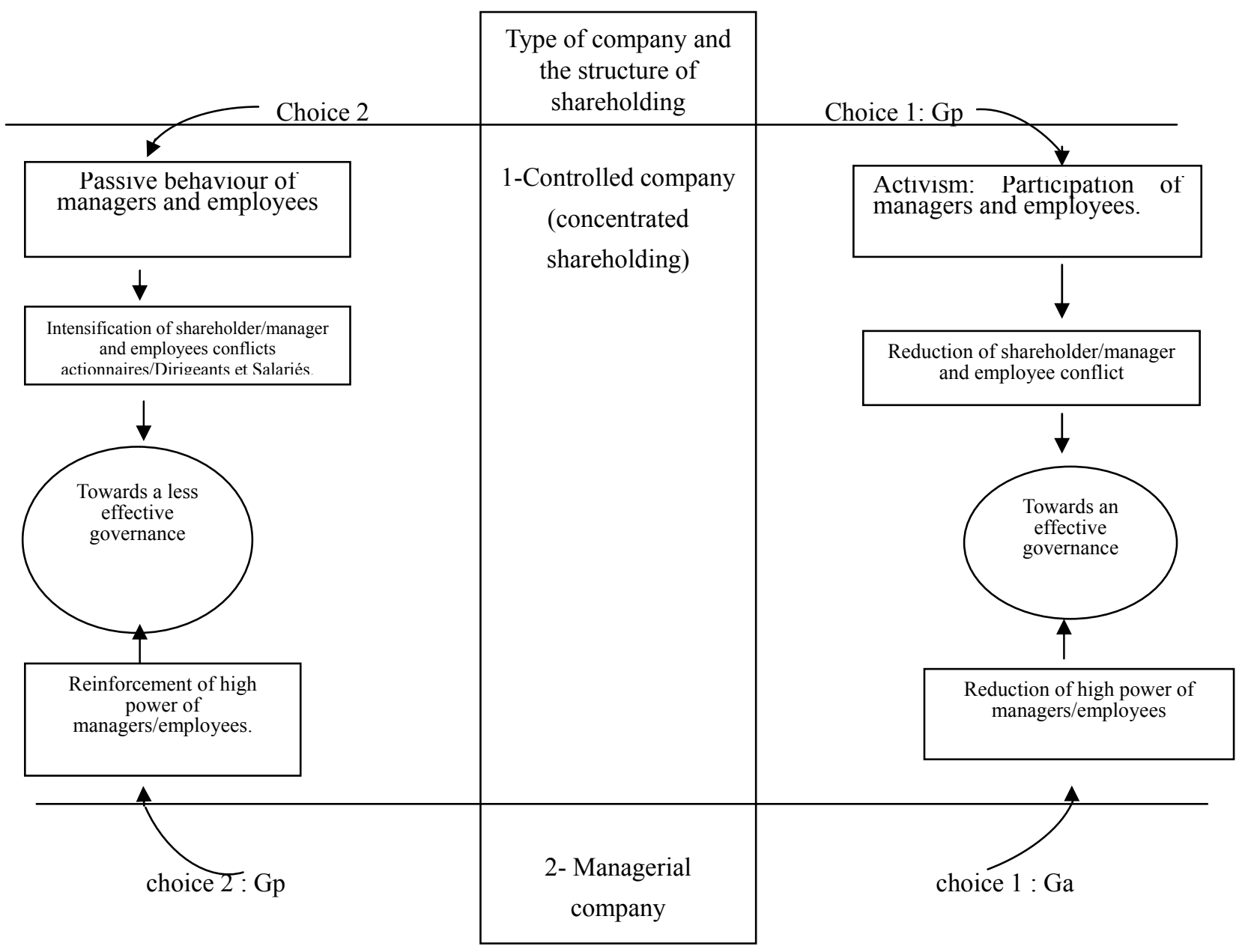

Figure 6. From a shareholder governance (Gs) to a partnership governance (Gp)

Source: NGOUNGO (2007) 


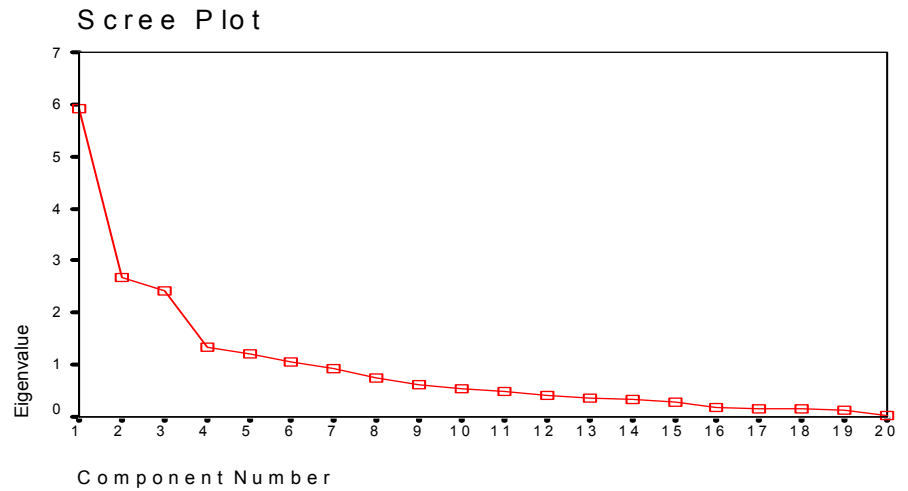

Figure 7. Cattel's cree-test

Source: Our statistical output using SPSS 10 software

Company without foreign shareholder

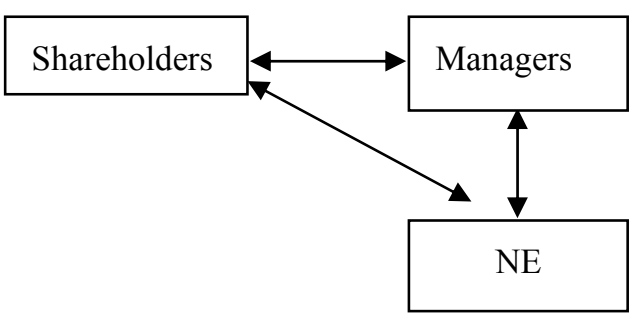

Company that has foreign shareholders

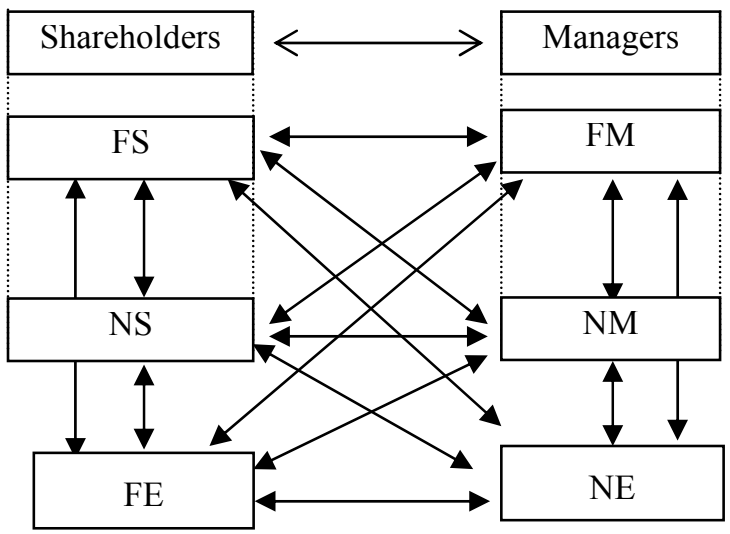

Figure 8. Company without foreign shareholder and Company that has foreign shareholders 